\title{
Correction
}

\section{Correction to: The utilization of bentonite enhanced termite mound soil mixture as filter for the treatment of paint industrial effluent}

\author{
Omobolaji Taofeek Opafola ${ }^{1}$ (D) Adekunle Olorunlowo David ${ }^{1} \cdot$ Fidelis Odedishemi Ajibade $^{2}$. \\ Hezekiah Oluwoye Adeyemi ${ }^{3}$. Olorunfunmi Isimioluwa Solana ${ }^{4} \cdot$ Babashola Dapo Odugbose $^{5}$
}

Published online: 19 March 2021

(c) The Author(s) 2021 OPEN

\section{Correction to: SN Applied Sciences (2021) 3:415 https://doi.org/10.1007/s42452-021-04405-x}

There was a typing error in the fifth author's name in the initial online publication. The original article has been corrected.

Open Access This article is licensed under a Creative Commons Attribution 4.0 International License, which permits use, sharing, adaptation, distribution and reproduction in any medium or format, as long as you give appropriate credit to the original author(s) and the source, provide a link to the Creative Commons licence, and indicate if changes were made. The images or other third party material in this article are included in the article's Creative Commons licence, unless indicated otherwise in a credit line to the material. If material is not included in the article's Creative Commons licence and your intended use is not permitted by statutory regulation or exceeds the permitted use, you will need to obtain permission directly from the copyright holder. To view a copy of this licence, visit http://creativecommons. org/licenses/by/4.0/.

Publisher's Note Springer Nature remains neutral with regard to jurisdictional claims in published maps and institutional affiliations.

The original article can be found online at https://doi.org/10.1007/s42452-021-04405-x.

Omobolaji Taofeek Opafola, opababa@gmail.com | 'Department of Civil Engineering, Olabisi Onabanjo University, Ibogun Campus, P.M.B. 5026, Ifo, Ogun State, Nigeria. ${ }^{2}$ Department of Civil Engineering, Federal University of Technology, P.M.B. 704, Akure, Ondo State, Nigeria. ${ }^{3}$ Department of Mechanical Engineering, Olabisi Onabanjo University, Ibogun Campus, P.M.B. 5026, Ifo, Ogun State, Nigeria. ${ }^{4}$ Department of Home Science and Hospitality Management, Olabisi Onabanjo University, Ayetoro Campus, P.M.B. 0012, Ayetoro, Ogun State, Nigeria. ${ }^{5}$ Department of Agricultural Engineering, Olabisi Onabanjo University, Ibogun Campus, P.M.B. 5026, Ifo, Ogun State, Nigeria. 